\title{
Use of Seaweed (Sargassum tenerrimum) extract as gel enhancer for lesser sardine (Sardinella brachiosoma) surimi
}

\author{
Snehal Subhash Shitole • Amjad Khansaheb Balange • \\ Shardul Sham Gangan
}

Received: 28 August 2013/Accepted: 30 November 2013/Published online: 18 March 2014

(C) The Author(s) 2014. This article is published with open access at Springerlink.com

\begin{abstract}
Surimi is a Japanese word for washed fish mince which can be used as a raw material for the preparation of various analogue products like shrimp, lobster, crab analogue, etc. which have a very good demand in the international market. Most of the lean fishes in tropical environment have good gel-forming ability, compared with fatty fishes but due to overexploitation of lean fishes its stock got depleted. However, fatty fish like lesser sardine have low gel-forming ability due to high fat content. Recently, plant phenolic compounds have been used successfully as protein cross-linkers. Therefore, an attempt has been made in the present investigation to extract phenolic compounds from seaweed which is abundantly available at the west coast of India and to use it as protein cross-linker in fatty fish, i.e. lesser sardine surimi. Water seaweed (Sargassum tenerrimum) extract (WSE) contained $16.24 \mathrm{mg}$ tannin/g of dry seaweed powder. Effects of WSE at different levels ( $0.5-2.5 \%$ of Surimi) on the properties of gels from lesser sardine (Sardinella brachiosoma) surimi were investigated in comparison with surimi gel without seaweed extract. Gels added with $2.0 \%$ WSE had the increases in gel strength by $76.27 \%$, compared with the control (without addition of extracts). The lowered expressible moisture content was observed in surimi gels incorporated with $2 \%$ WSE. Slight decreases in whiteness were observed with increasing seaweed extract concentration. Protein solubility $\%$ also indicates that, sample prepared with $2 \%$ WSE have low solubility in 0.6 M KCL. There was no significant difference in the $\mathrm{pH}$ values of treated surimi gel and control surimi gel samples. Therefore, it may be concluded that the extract of seaweed can be used as gel enhancer in lesser sardine surimi with coincidental increase in texture likeness and had no negative effect on colour and odour likeness.
\end{abstract}

Keywords Cross-linking $\cdot$ Phenolic compounds $\cdot$ Gelation $\cdot$ Seaweed $\cdot$ Lesser sardine $\cdot$ Surimi

\author{
Abbreviation \\ WSE Water seaweed extract
}

\author{
S. S. Shitole · A. K. Balange ( $₫)$ \\ Central Institute of Fisheries Education, Off Yari Road, Panch Marg, Versova, Andheri (W), Mumbai 400061, \\ Maharashtra, India \\ e-mail: amjadbalange@cife.edu.in \\ S. S. Shitole \\ e-mail: snehalshitole98@gmail.com \\ S. S. Gangan \\ Khar Land Research Station, Bunder Road, Near old court, Panvel, Raigad/Maharashtra, India \\ e-mail: shardul76@rediffmail.com
}




\section{Introduction}

In recent times, importance of total utilisation of fish landings, including under-utilised fish species as human food, has been realised because of the diminishing marine catch and increasing consumer interest in fish products. While several methods are available for value addition of fish, surimi technology has been recognised as one of the most successful techniques for low-cost fish utilization. Surimi gel is a three-dimensional myofibrillar protein network. The textural properties developed during gelation are normally expressed in terms of gel strength, which is the basic parameter for determining the quality and price of surimi (Benjakul et al. 2004a). To increase the gel strength of surimi, various food grade ingredients have been used. However, the addition of these ingredients poses adverse effect on the surimi gel, particularly on off-flavour or offcolour development (Rawdkuen and Benjakul 2008). In general, the lean fish have been used for the surimi production but overexploitation of the lean fish has resulted in the insufficiencies of those species as raw material. The use of under-utilised small pelagic fish species, such as sardine and mackerel could be a better alternative for the lean fish but their use for surimi production is limited mainly due to the large quantity of lipids and myoglobin in the muscle tissue (Chaijan et al. 2004). Furthermore, pelagic fish has been found to possess the high proteolytic activity, which is associated with gel softening. To alleviate the problem, protein additives have been widely used to enhance the gel strength of the surimi via inhibition of proteolysis caused by an endogenous proteinase (Benjakul et al. 2004b). Recently, the interactions between phenolic compounds and proteins have been paid more attention in the processing of certain food products. There have been a few studies describing the cross-linking ability of phenolic compounds with proteins (Rawel et al. 2002; Strauss and Gibson 2004). Balange and Benjakul (2009a) reported a significant increase in the gel strength of Bigeye snapper surimi when commercial phenolic compounds in oxidised forms were added. Among all oxidised phenolic compounds used, oxidised tannic acid exhibited the highest gel strengthening effect, compared with oxidised ferulic acid, oxidised catechin and oxidised caffeic acid (Balange and Benjakul 2009a).

Brown seaweed (Sargassum tenerrimum) is very common in the west coast of India. Seaweed contains phenol level up to $20 \%$ of their dry weight (Connan and Stengel 2007). Tannin substances with phenolic character occur in marine algae in the physodes of Phaeophyta, such as Sargassum species (Vimalabai et al. 2004). Seaweeds have been identified as a rich source of bioactive compounds and their extracts also exhibit antimicrobial potential against the pathogenic microbes. Pharmacologist, physiologists and chemist have been paying increasing attention to the marine organisms particularly on seaweeds for screening bioactive substances (Arunkumar et al. 2010). The bioactive molecules-phenolic compounds, i.e. the secondary metabolites, mainly as a phlorotannins are found at high level in marine brown algae (Ragan and Glombitza 1986). The preparation of seaweed extract containing phenolic compounds could increase the value of those seaweeds and the novel natural additives can be applied in food industry, especially surimi industry.

However, there is a little information on the utilisation of seaweed extract as the cross-linking agents in food proteins, particularly myofibrillar proteins. Therefore, the objectives of this research were to extract and quantify total phenolic compounds in the seaweed ( $S$. tenerrimum) and to use the extracts as gel enhancer in surimi from lesser sardine (Sardinella brachiosoma).

\section{Methods}

Chemicals

Tannic acid Powder Pure (Molychem, Product code: 19280, Mumbai, India), sodium carbonate (Thomas Dekker, Mumbai, India), Folin-Ciocalteu Phenol reagent (Sisco Research Laboratory, Mumbai, India) were obtained.

Preparation of seaweed extracts

Brown seaweed (S. tenerrimum) species available along Ratnagiri coast, Maharashtra, India were collected by hand-picking method. Collected samples were packed in polyethylene bags and transported to the Lab. Collected seaweeds were washed with fresh water and were subjected to sun drying for 14 days. 
Standardisation of extraction of phenolic compounds from dry seaweed

The sundried seaweeds were ground using a portable grinding machine (Kenstar, Senator, Japan). Then seaweed powder was sieved with Test sieve (Jayant scientific IND, India) using a screen with a diameter of $0.07 \mathrm{~mm}$. Seaweed extract was then prepared according to the method described by Zahra et al. (2007) with slight modification. The different weights of seaweed powder, i.e. 0.5, 1, $1.5 \mathrm{~g}$ were taken and dissolved in $100 \mathrm{ml}$ distilled water and labelled as A, B and C, respectively. Then the mixtures were autoclaved at $121{ }^{\circ} \mathrm{C}$ for $15 \mathrm{~min}$ in Autoclave of 'Equitron' brand (medical instruments mfg. Co, Mumbai). The autoclaved treatment followed by centrifugation $(2,000 \times g$ for $10 \mathrm{~min})$, with centrifuge (Hettich Zentrifugen, D-78532; Tuttlingen, Germany) and then the supernatant was evaporated directly on flame, to get a final volume $10 \mathrm{ml}$ and extract was collected in glass bottles.

Quantification of total phenolic content

Quantification of total phenolic compounds in different seaweed extracts was carried out according to the method of Kuda et al. (2005). Briefly, $0.4 \mathrm{ml}$ aliquot of the each seaweed extract from different dilutions of each sample was transferred into a test tube containing $0.8 \mathrm{ml}$ of the $10 \%$ Folin-Ciocalteu phenol reagent. After $3 \mathrm{~min}, 1.6 \mathrm{ml}$ of the $10 \%$ sodium carbonate solution was added. The contents were mixed routinely, using glass rod and left to stand at room temperature for $1 \mathrm{~h}$ in dark. Absorbance was recorded at $750 \mathrm{~nm}$ using a spectrophotometer (Thermo Scientific Genesys $10 \mathrm{UV}$, USA). Tannic acid was used as standard for quantification of phenolic content in seaweed. Absorbance for tannic acid solution was recorded at different concentrations and used as the standard. Estimation of the phenolic contents was carried out in triplicates and the results were expressed as mg of Tannic acid equivalent (TA)/g dry sample. Blank for each extract was prepared in the same manner, except that distilled water was used instead of Folin-Ciocalteu reagent.

Surimi gel preparation

Fresh surimi from lesser sardine (S. brachiosoma) (without prior freezing and cryoprotectants) was purchased from M. D. Naik, Pethkilla, Ratnagiri, Maharashtra, India. Surimi gel was prepared according to the method described by Balange and Benjakul (2009c) with slight modification. Chopped surimi was mixed with seaweed extract (Phenolic compounds) containing $16.24 \mathrm{mg}$ tannin/g of dry seaweed powder, at different concentrations, i.e. $0.0,0.5,1.0,1.5,2.0$ and $2.5 \%$ (\% based on weight of surimi) and was then chopped for $5 \mathrm{~min}$ at low temperature to obtain a homogeneous surimi along with seaweed extract. Prepared surimi samples (with seaweed extract) and surimi with cryoprotectants (without seaweed extract) were then packed and stored overnight into cold storage maintained at $-20{ }^{\circ} \mathrm{C}$.

On next day, frozen surimi was tempered by keeping at room temperature for $1 \mathrm{~h}$, until the core temperature reached $0-2{ }^{\circ} \mathrm{C}$. The surimi was then cut into small pieces with an approximate thickness of $1 \mathrm{~cm}$. Chopped surimi was placed in a mincer and mixed with $3 \%$ salt ( $73 \%$ surimi moisture content). The final moisture content for all surimi gel samples were adjusted to $80 \%$. The mixture was chopped for 20 min at low temperature to obtain a homogeneous sol. The sol was then stuffed into krehalon casing (UK) with a diameter of $2.5 \mathrm{~cm}$ and both ends of the casing were sealed tightly. Sols were incubated at $40{ }^{\circ} \mathrm{C}$ for $30 \mathrm{~min}$, followed by heating at $90{ }^{\circ} \mathrm{C}$ for $20 \mathrm{~min}$ in water bath (Bio-Technics India, Mumbai). The control gels were prepared in similar way but without seaweed extract addition. After heating, prepared surimi gels were chilled in ice for $20 \mathrm{~min}$ and stored overnight in an incubator (Metalab, Mumbai, India) at $4{ }^{\circ} \mathrm{C}$ prior to analysis.

Measurement of gel properties

\section{Textural analysis}

Textural analysis of gels was performed using a texture analyser: RHEO TEX (Type: SD-700, Japan). Gels were tested at room temperature. Prepared surimi gels were cut into five cylindrical shaped pieces of $2.5 \mathrm{~cm}$ in length. The breaking force (gel strength) and deformation (elasticity/deformability) were measured for each sample by keeping the pieces of each sample into the texture analyzer equipped with a spherical plunger 
( $5 \mathrm{~mm}$ diameter; $60 \mathrm{~mm} / \mathrm{min}$ plunger speed). The probe was pressed into the cut surface of a gel specimen perpendicularly at a constant speed, until puncture occurred. The force in gram $(\mathrm{g})$ required to puncture into the gel (breaking force) and the distance (in $\mathrm{mm}$ ) at which the ball probe punctured into the gel (deformation) were recorded. Gel strength for each surimi gel was measured from respective breaking force and deformation.

Determination of whiteness

Whiteness was measured using whiteness meter (MINIOLTA, Chroma meter CR-400; Japan), used in surimi industry for whiteness measurement.

Determination of expressible moisture content

Expressible moisture content was measured according to the method of Balange and Benjakul (2009b) with a slight modification. Gel sample with a thickness of $0.5 \mathrm{~cm}$ was weighed $(X)$ and placed between three sheets of Whatman paper No. 4 at the bottom and two sheets on the top of the sample. The standard weight $(5 \mathrm{~kg})$ was placed at the top and held for $2 \mathrm{~min}$. The sample was then removed from the papers and weighed again $(Y)$. Expressible moisture content was calculated using the following equation:

$$
\text { Expressible moisture content }(\%)=100[(X-Y) / X]
$$

Determination of $\mathrm{pH}$

$\mathrm{pH}$ was measured using $\mathrm{pH}$ meter (Sentex, California, USA). Surimi gel (5 g) was weighed and homogenised with $45 \mathrm{ml}$ of distilled water at a speed of $800 \mathrm{rpm}$ for $1 \mathrm{~min}$ and filtered using a filter paper (Whatman paper No. 1). The $\mathrm{pH}$ of filtrate was recorded using a $\mathrm{pH}$ meter.

Sensory evaluation

Lesser sardine gels without and with seaweed extract were equilibrated at room temperature and evaluated for appearance, colour, taste, texture, odour and overall liking by 30 untrained panellists, in comparison with the control gel (without phenolic compound). A nine-point hedonic scale, in which a score of $1=$ not like very much, $5=$ neither like nor dislike and $9=$ like extremely, was used for evaluation. High score indicated good quality and vice versa (Meilgaard et al. 1990).

Solubility determination

Solubility of protein in surimi gel was determined as described by Benjakul et al. (2001). Finely chopped gel sample $(1 \mathrm{~g})$ was solubilised with $0.6 \mathrm{M} \mathrm{KCl}$. The mixture was homogenised for $1 \mathrm{~min}$, boiled for $2 \mathrm{~min}$ and stirred for $4 \mathrm{~h}$ at room temperature $\left(28-30^{\circ} \mathrm{C}\right)$ using a magnetic stirrer (Analisis, Mumbai, India). The mixture was centrifuged at $10,000 \times g$ for $30 \mathrm{~min}$. Two $\mathrm{ml}$ of $50 \%(\mathrm{w} / \mathrm{v})$ cold trichloroacetic acid (TCA) were added to $10 \mathrm{ml}$ of supernatant. The mixture was kept at $4{ }^{\circ} \mathrm{C}$ for $18 \mathrm{~h}$ prior to centrifugation at $10,000 \times g$ for 20 min. The precipitate was washed with $10 \%$ (w/v) TCA, followed by solubilising in $0.5 \mathrm{M} \mathrm{NaOH}$. Protein concentration was determined by the Biuret method (Robinson and Hodgen 1940). Solubility of protein in surimi samples was expressed as the percentage of total protein in surimi gels solubilised directly in $0.5 \mathrm{M} \mathrm{NaOH}$.

SDS-Polyacrylamide gel electrophoresis

Protein patterns of surimi gels added with or without WSE at various concentrations were analysed by SDS-PAGE according to the method of Laemmli (1970). To prepare the protein sample, $27 \mathrm{ml}$ of $5 \%$ (w/v) SDS solution heated to $85^{\circ} \mathrm{C}$ were added to the sample $(3 \mathrm{~g})$. The mixture was then homogenised using a homogeniser (Polytron, Kinematica, Switzerland) at a speed 11,000 rpm for $2 \mathrm{~min}$ and incubated at $85^{\circ} \mathrm{C}$ for $1 \mathrm{~h}$ to dissolve total proteins. The samples were centrifuged at 3,500 $\times \mathrm{g}$ for $20 \mathrm{~min}$ to remove undissolved debris. Protein concentration of the supernatant was determined by the Biuret method (Robinson and Hodgen 1940) 
using bovine serum albumin as a standard. The sample was then mixed with sample buffer $(4 \mathrm{ml}$ of $10 \%$ SDS, $2 \mathrm{ml}$ of glycerol, $1 \mathrm{ml}$ of $\beta$-Mercaptoethanol, $2.5 \mathrm{ml}$ of $0.5 \mathrm{M}$ Tris- $\mathrm{HCl}(\mathrm{pH} 6.8$ ), and $0.03 \mathrm{~g}$ Bromophenol blue) at $1: 1$ ratio $(\mathrm{v} / \mathrm{v})$. The samples $(20 \mu \mathrm{g}$ protein) were loaded onto the polyacrylamide gel made of $10 \%$ running gel and $4 \%$ stacking gel and subjected to electrophoresis at a constant current of $15 \mathrm{~mA}$ per gel using a Hoefer Mini Electrophoresis (San Francisco, USA). After separation, the proteins were stained with $0.02 \%(\mathrm{w} / \mathrm{v})$ Coomassie Brilliant Blue R-250 in $50 \%(\mathrm{v} / \mathrm{v})$ methanol and $7.5 \%(\mathrm{v} / \mathrm{v})$ acetic acid and destained with $50 \%$ methanol (v/v) and $7.5 \%(\mathrm{v} / \mathrm{v})$ acetic acid, followed by $5 \%$ methanol (v/v) and $7.5 \%$ $(\mathrm{v} / \mathrm{v})$ acetic acid.

Scanning electron microscopy (SEM)

Microstructure of surimi gels without WSE, i.e. control (Sample A) and with $2 \%$ WSE (Sample B) was determined using scanning electron microscope. The surimi gel samples were cut into small pieces and dried with pressure treatment inside the scanning electron microscope. The specimens were observed with a scanning electron microscope (FEI QUANTA 200 ESEM AND EDAX SYSTEM, Oregon, USA) at an accelerated voltage of $20 \mathrm{kV}$.

Statistical analysis

Data were subjected to analysis of variance (ANOVA). Comparison of means was carried out by Duncan's multiple-range tests. Analysis was performed using a SPSS package (SPSS 10.0 for Windows, SPSS Inc, Chicago, IL, USA).

\section{Results and discussion}

Quantification of total phenolic content

The total phenolic content extracted with water for three different sizes of seaweed powder is depicted in Table 1. It was observed that the extract prepared with $0.5 \mathrm{~g}$ dry seaweed powder contained $12.70 \mathrm{mg}$ tannin/g of dry seaweed powder. Extract prepared with $1.0 \mathrm{~g}$ dry seaweed powder contained $16.24 \mathrm{mg} \operatorname{tannin} / \mathrm{g}$ of dry seaweed powder. The higher amount of phenolic content was found in the extract prepared with $1.5 \mathrm{~g}$ seaweed powder was $21.85 \mathrm{mg}$ tannin/g of dry seaweed powder. From results it was concluded that, with increasing quantity of seaweed powder, phenolic content in extract was also increased. This was in agreement with earlier reports about total phenolic content in the seaweed extract prepared with $1.0 \mathrm{~g}$ seaweed powder (Zahra et al. 2007). However, with $1.5 \mathrm{~g}$ seaweed powder, the colour of the extract became dark as compared with 0.5 and $1.0 \mathrm{~g}$ seaweed powder extract. So, it was decided to use $1.0 \mathrm{~g}$ seaweed powder as standard sample size for extraction of phenolic compound and for further use in determining quality of surimi.

Hwang et al. (2010) reported that, freeze dried hot water extract from Sargassum hemiphyllum contained $0.240 \mathrm{mg}$ phenolic compound $/ \mathrm{ml}$ of extract. Zubia et al. (2008) observed the phenolic content in Sargassum mangarevense was $2.45 \%$, whereas Zahra et al. (2007) found total phenolic compounds in Sargassum boveanum water extract was about $17 \pm 0.492 \mathrm{mg}$ catechin equivalent/g of dry sample and also recorded the total phenolic content in ethanol extract for same species was about $0.9 \mathrm{mg}$ catechin equivalent/g of dry sample.

Effect of WSE on gel strength of lesser sardine surimi gel

Lesser sardine surimi gels were prepared from $0,0.5,1.0,1.5,2.0$ and $2.5 \%$ seaweed extract concentration containing with total phenolic compound of $16.24 \mathrm{mg}$ tannin/g of dry seaweed powder (Fig. 1). It was observed that there was increase in gel strength with the increase in concentration of the WSE up to a particular level. An experiment was conducted to see the effect of overnight frozen storage on the surimi samples kept without and with cryoprotectants at $-20{ }^{\circ} \mathrm{C}$. All the surimi gels prepared with WSE and without addition of any cryoprotectants and stored at $-20^{\circ} \mathrm{C}$ have good gel formation compared with gel prepared 
Table 1 Total phenolic content in seaweed extract at different concentrations

\begin{tabular}{ll}
\hline Sample & mg tannin/g of dry seaweed powder \\
\hline A & $12.70 \pm 0.76^{\mathrm{a},{ }^{*}}$ \\
B & $16.24 \pm 0.32^{\mathrm{b}}$ \\
C & $21.85 \pm 0.67^{\mathrm{c}}$ \\
\hline
\end{tabular}

\pm SE of mean $(n=3)$

* Different superscripts in the same column indicates the significant difference $(P<0.05)$

Fig. 1 Effect of WSE on lesser sardine surimi gel strength. *Different letters indicate the significant difference $(P<0.05)$. \pm Standard error of mean $(n=3)$

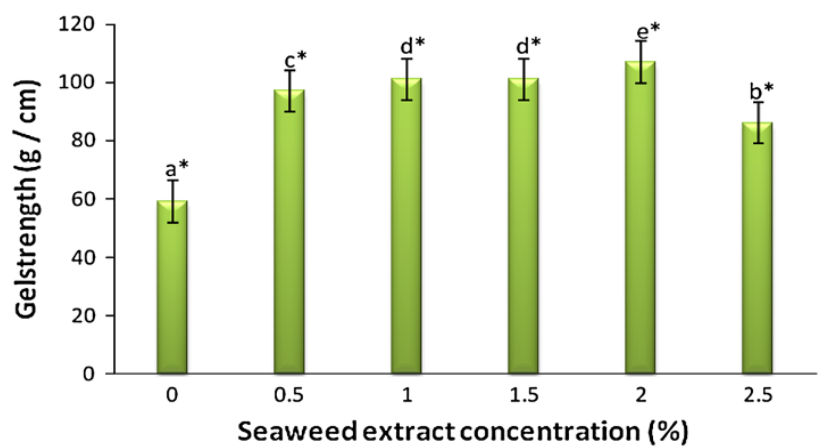

with cryoprotectants and without any WSE (data not shown). The overnight storage at $-20{ }^{\circ} \mathrm{C}$ without any cryoprotectants might not have affected the gel-formation ability of myofibrillar proteins. Surimi gel with $2 \%$ WSE had the significant $(P<0.05)$ increase in gel strength up to $104 \mathrm{~g} / \mathrm{cm}$, compared with that of the control gel, i.e. $51 \mathrm{~g} / \mathrm{cm}$. For gels added with $0.5 \%$ of WSE, the minor increase in gel strength up to $97 \mathrm{~g} / \mathrm{cm}$ was observed compared with that of the control gel, i.e. $51 \mathrm{~g} / \mathrm{cm}$. Progressive increase in gel strength was observed when WSE concentrations were used from 0.5 to $2.0 \%$. With $2.5 \%$ WSE concentration, gel strength decreased, but the gel strength was higher than that of control. Use of WSE at $2 \%$ concentration, increased the lesser sardine surimi gel strength by $76.27 \%$; compared to that of control surimi gel.

Lesser sardine surimi gel prepared with addition of $2 \%$ WSE showed significant increase in gel strength by $76.27 \%$ as compared with control. This increase in gel strength might be attributed to the cross-linking activity of phenolic compounds present in the seaweed extract which could induce the formation of both covalent and non-covalent bonds of gel matrix (Prigent et al. 2003). The result is in accordance with that of Balange and Benjakul (2009b) who reported the increases in breaking force and deformation of mackerel surimi with the addition of kiam wood extract containing phenolic compound. The decrease in gel strength of surimi gel with increasing concentration of WSE above $2.0 \%$ in the present investigation may be associated with self-aggregation of phenolic compounds, leading to the loss in capability of protein cross-linking. De Freitas and Mateus (2001) found that the high concentration of phenolic compounds lowers the efficiency in interacting with protein.

\section{Effect of WSE on expressible moisture}

The lowest expressible moisture content of lesser sardine surimi was found when WSE at optimum level (2 \%) was added (Fig. 2). Increase in expressible moisture content was noted in surimi gel prepared without WSE. Moreover, expressible moisture content was high in surimi prepared with WSE above optimum level. Among the WSE, the extract added at $2 \%$ in surimi yielded the gel with the lowest expressible moisture content $(P<0.05)$.

At the optimal level, the cross-linking of proteins in the lesser sardine surimi gels could be enhanced. This resulted in the formation of stronger network with greater water-holding capacity. Among the extracts WSE at a level of $2.0 \%$ yielded the gel with the lowest expressible moisture content. This reconfirmed that WSE addition resulted in gel strengthening. As a result, gel network with capability of imbibing water could be obtained. Balange and Benjakul (2009b) also reported lowest expressible moisture content of mackerel surimi 
Fig. 2 Effect of WSE on expressible moisture content of lesser sardine surimi gel. *Different letters indicate the significant difference $(P<0.05)$. \pm Standard error of mean $(n=3)$
Fig. 3 Effect of WSE on lesser sardine surimi whiteness. *Different letters indicate the significant difference $(P<0.05)$. \pm Standard error of mean $(n=3)$
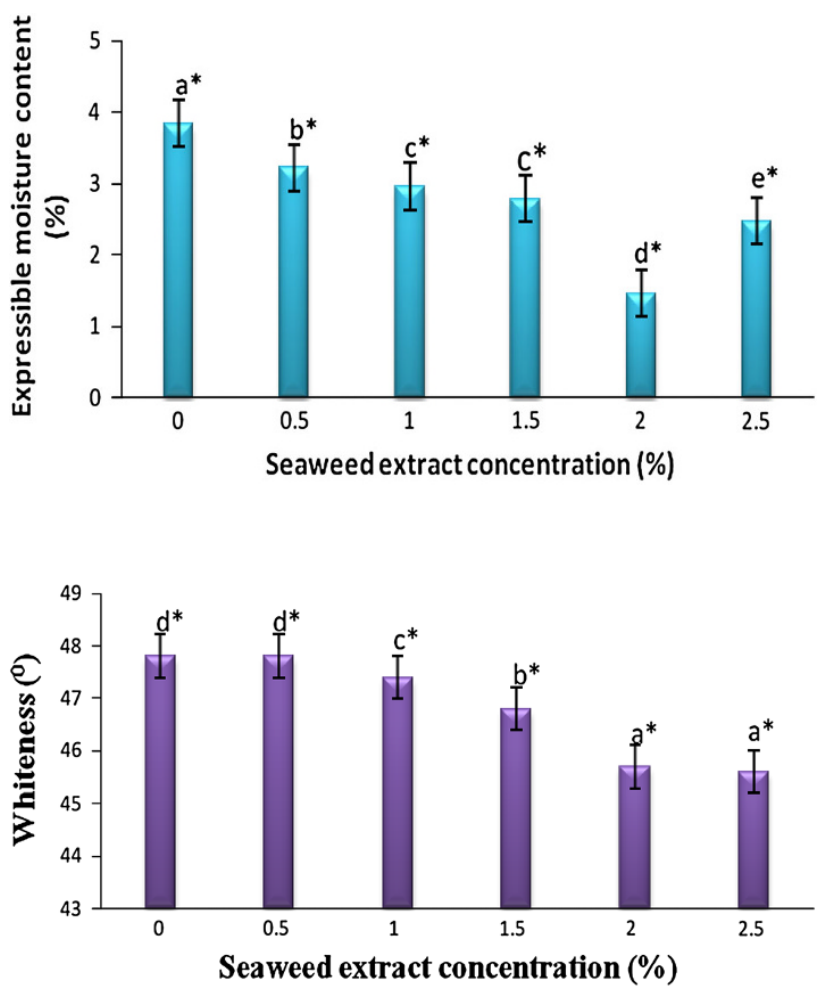

gel with water kiam wood extract added at optimum level. Also, increase in expressible moisture content was found in surimi gels added with water kiam wood extract above optimum level. Balange and Benjakul (2009c) also reported lowest expressible moisture content in gels with addition of $0.50 \%$ oxidised tannic acid.

Effect of WSE on whiteness of lesser sardine surimi gel

Decrease in whiteness of lesser sardine surimi gels was observed as the levels of the WSE were increased (Fig. 3). From the observations, it was clear that with increasing concentration of WSE the whiteness decreased. It was $44.60^{\circ}$ when compared with that of control of $47.81^{\circ}$. It was observed that, there was slight difference among treatment effect on whiteness of surimi gel $(P<0.05)$.

Evaporation of water extract at high temperature for a long time enhanced the darkening of water extract. Pansera et al. (2004) used the process of hydrosolubilisation at $100{ }^{\circ} \mathrm{C}$ for the extraction of tannin and found that the extraction process at high temperature motivates a hydrocracking of sugar and other organic compounds with darkening of the final product. From the result, surimi gel added with WSE had a slight decrease in whiteness.

Effect of WSE on the pH of lesser sardine surimi gel

In the present study, addition of WSE-containing phenolic compounds showed no significant difference in $\mathrm{pH}$ $(P>0.05)$ with increasing concentration of WSE in surimi gel (Fig. 4). The WSE added in lesser sardine surimi gel contained higher amount of phenolic compounds, i.e. polyphenols, possessing one or more aromatic rings bearing hydroxyl substituent (Parr and Bolwell 2000), which might have resulted in slight increase in $\mathrm{pH}$ of surimi gel in the present investigation which was not significant compared with control surimi gel sample.

Effect of WSE on the protein solubility of lesser sardine surimi gel

Solubility of surimi gels added with different concentrations of WSE is shown in Fig. 5. Solubility was found to be low in surimi gel prepared with $2 \%$ WSE. However, all the gel samples prepared with WSE 
Fig. 4 Effect of dry WSE on lesser sardine surimi $\mathrm{pH}$. Not significant difference $(P>0.05)$. \pm Standard error of mean $(n=3)$

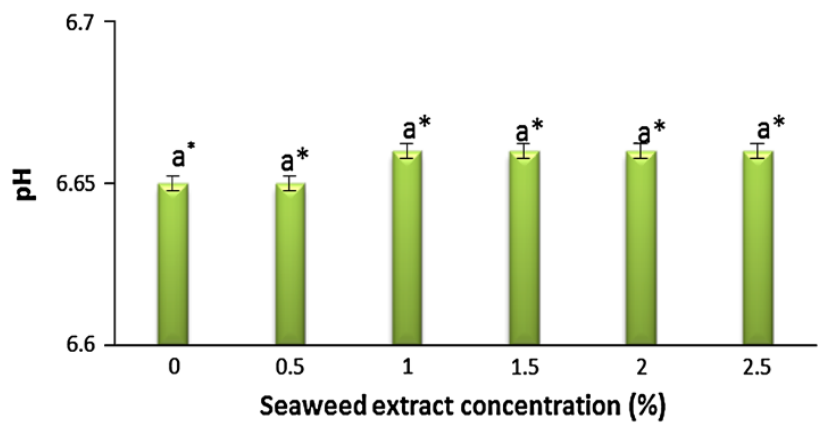

Fig. 5 Effect of WSE on lesser sardine surimi gel solubility. * Different letters indicate the significant difference $(P<0.05)$. \pm Standard error of mean $(n=3)$

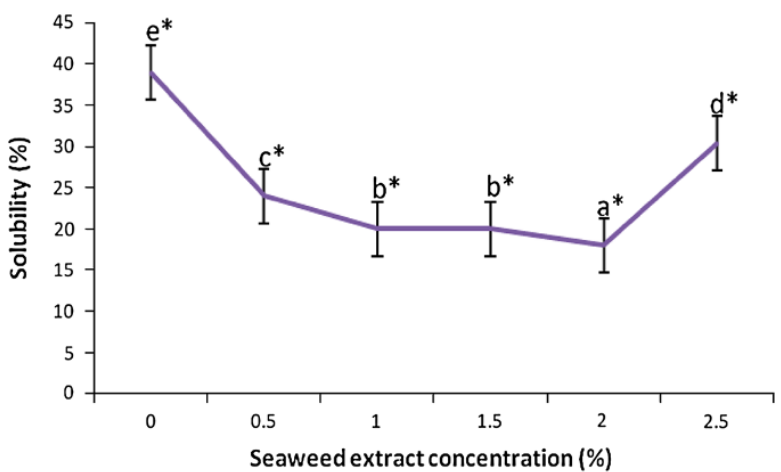

have low solubility as compared with control gel. In the gels with and without WSE, the decrease in solubility suggests the formation of protein aggregates during setting and heating (Balange and Benjakul 2009a). Also hydrophobic interactions may occur between phenolic compounds and hydrophobic amino acids such as alanine, valine, isoleucine, leucine, methionine, phenylalanine, tyrosine, tryptophan, cysteine and glycine residues (Prigent et al. 2003). The lower solubility obtained in the present investigation is very well correlating with higher gel strength and lower expressible moisture when added with $2 \%$ WSE in surimi gel.

Effect of WSE on the sensory properties of lesser sardine surimi gel

Likeness scores of the control gels (without extract) and those added with the WSE are depicted in Fig. 6. The results revealed that lesser sardine surimi gel prepared with WSE at the $2 \%$ concentration had highest texture and overall acceptability score. The trend observed for textural scores are well reflected by the similar trends for the increasing gel strength and decreasing expressible water values. The explanation given elsewhere for gel strength and expressible water holds good here. Organoleptically, panellist could not distinguish product for their colour but more preference was found for appearance, odour, taste and texture of surimi gels prepared with seaweed extract. Balange and Benjakul (2009b) also reported the highest overall acceptability for surimi gel prepared with $0.15 \%$ ethanolic kiam wood extract, which exhibited highest surimi gel strength.

Effect of WSE on the protein pattern of lesser sardine surimi gel

The protein patterns of surimi gels without and with the addition of WSE are depicted in Fig. 7. For gels with addition of $2.0 \%$ WSE, the MHC band disappeared almost completely. The result suggested that MHC was cross-linked by phenolic compounds to a high extent via non-disulphide covalent bonds. MHC was most susceptible to cross-linking during setting (Benjakul et al. 2004a). No marked changes in actin band intensity were observed between the control gel and those with addition of different concentrations of WSE. Additionally, dark flesh fish were reported to possess high autolytic activity (Benjakul et al. 2004b), which is associated with the poor gel properties. It was postulated that phenolic compounds might partially lower the 
proteolysis caused by endogenous proteinases. Cross-linked proteins were more likely less susceptible to proteolysis. This might be associated with gel strengthening in addition to enhanced protein cross-linking.

Effect of WSE on the microstructure of lesser sardine surimi gel

Microstructures of control gel without WSE (A) and with $2 \%$ WSE (B) are illustrated in Fig. 8. Surimi gel containing $2 \%$ WSE had a finer and continuous matrix than the control. This suggested that phenolic compounds might induce the cross-linking of protein, in which the protein filaments could be formed. Those filaments further underwent polymerization effectively, leading to a gel network with a fibrillar structure and finer strands with high capacity of imbibing water. This might be attributed to the greater number of binding sites in phenolic compounds, which in turn caused a higher aggregation. The finer and more ordered structure of the gel with $2 \%$ WSE added correlated with the highest gel strength (Fig. 1) as well as the lowest expressible moisture content (Fig. 2).

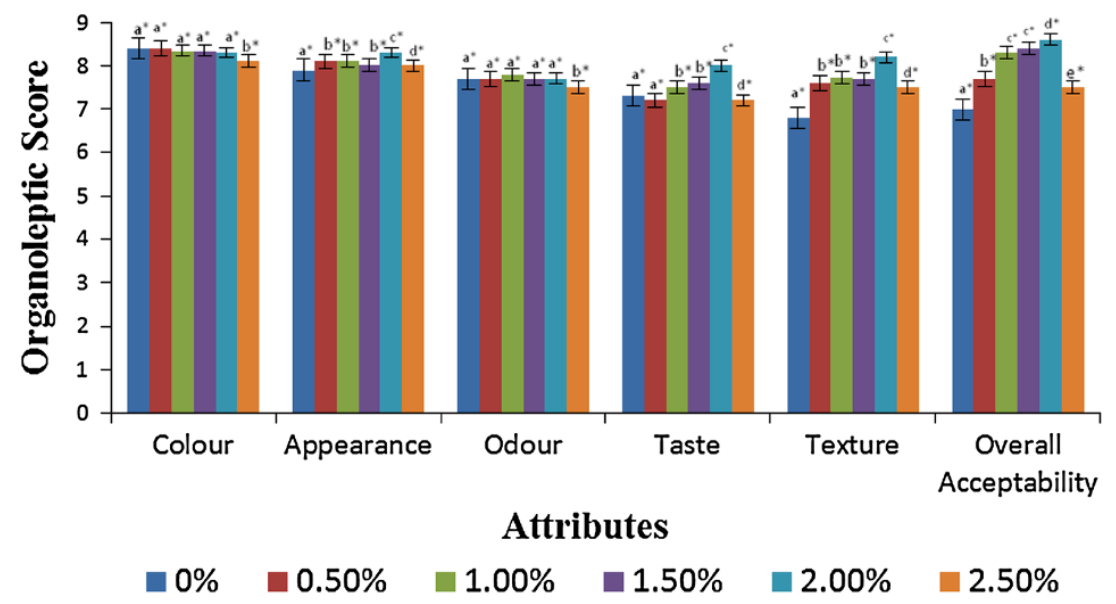

Fig. 6 Sensory score of lesser sardine surimi gels added with and without WSE. *Different letters indicate the significant difference $(P<0.05) . \pm$ Standard error of mean $(n=3)$

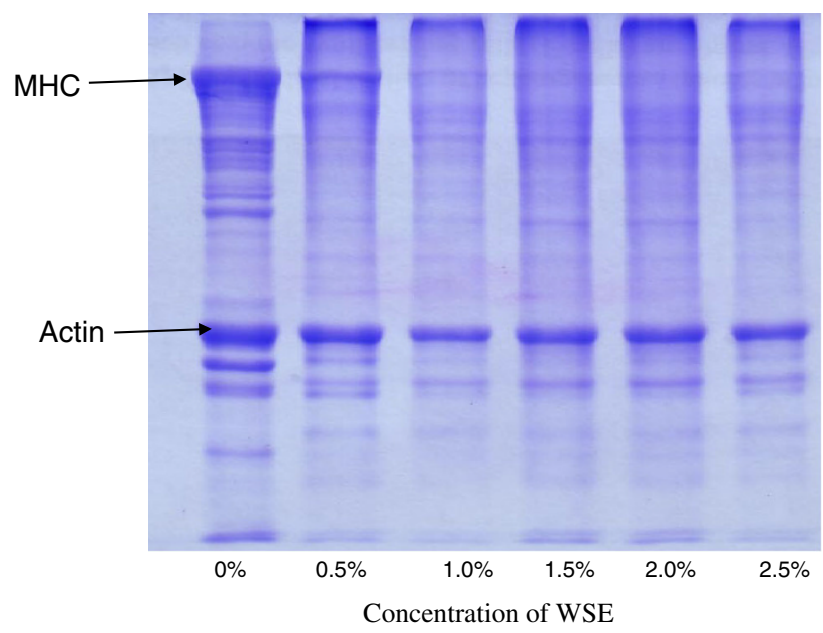

Fig. 7 Effect of WSE on protein pattern of lesser sardine surimi gel 
Sample A (Control i.e. without WSE)

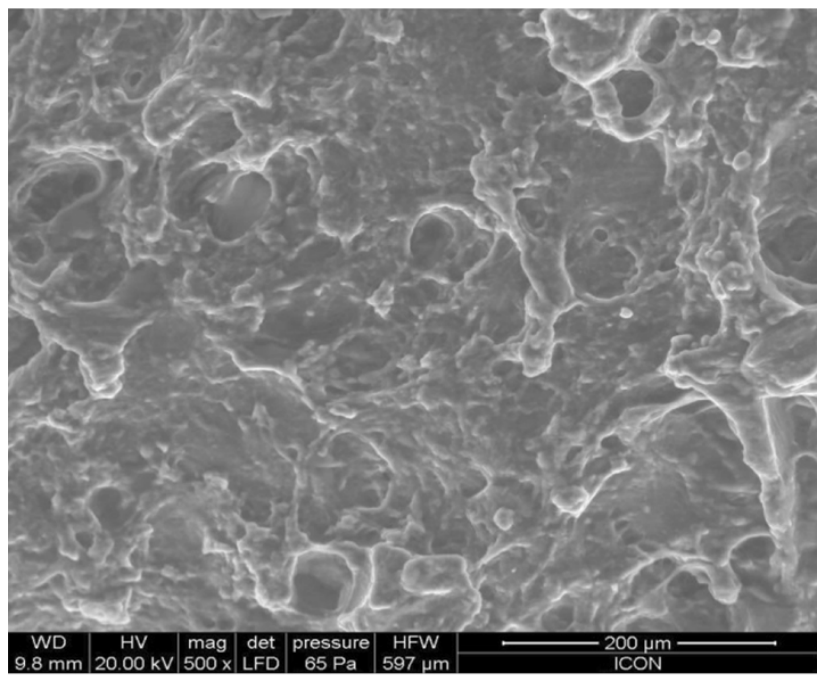

Sample B (With 2.0\% WSE)

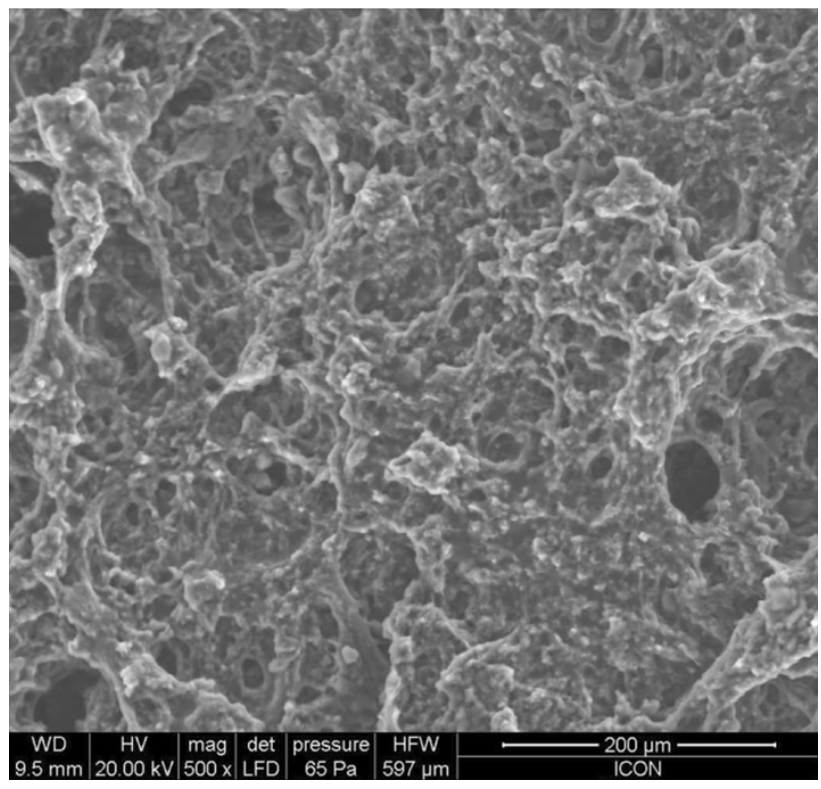

Fig. 8 Effect of WSE on microstructure of lesser sardine surimi gel

\section{Conclusions}

Seaweed extract had a potential in strengthening the gel of lesser sardine surimi when the optimum level $(2.0 \%)$ was introduced. Addition of seaweed extract had no detrimental effect on sensory properties of surimi gel. Thus, the extract from seaweed can be used as a natural gel enhancer for lesser sardine surimi industry.

Acknowledgments The authors would like to express their sincere thanks to The Director, CIFE, Mumbai and Associate Dean, Collage of Fisheries, Ratnagiri. This research was supported by the International Foundation of Science (IFS), Stockholm, Sweden through a grant to Dr Amjad K Balange.

Open Access This article is distributed under the terms of the Creative Commons Attribution License which permits any use, distribution, and reproduction in any medium, provided the original author(s) and the source are credited. 


\section{References}

Arunkumar K, Sivakumar S, Rengasamy R (2010) Review of bioactive potential in seaweeds (marine macroalgae): a special emphasis on bioactivity of seaweeds against plant pathogens. Asian J Plant Sci 9:227-240

Balange A, Benjakul S (2009a) Enhancement of gel strength of bigeye snapper (Priacanthus tayenus) surimi using oxidised phenolic compounds. Food Chem 113:61-70

Balange AK, Benjakul S (2009b) Use of kiam wood extract as gel enhancer for mackerel (Rastrelliger kanagurta) surimi. Int J Food Sci Technol 44:1661-1669

Balange AK, Benjakul S (2009c) Effect of oxidized phenolic compounds on the gel property of mackerel (Rastrelliger kanagurta) surimi. LWT Food Sci Technol 42:1059-1064

Benjakul S, Visessanguan W, Srivilai C (2001) Gel properties of bigeye snapper (Priacanthus tayenus) surimi as affected by setting and porcine plasma protein. J Food Qual 24:453-471

Benjakul S, Visessanguan W, Chantarasuwan C (2004a) Effect of high temperature setting on gelling characteristics of surimi from some tropical fish. Int J Food Sci Technol 39:671-680

Benjakul S, Visessanguan W, Tueksuban J, Tanaka M (2004b) Effect of some protein additives on proteolysis and gel-forming ability of lizardfish (Saurida tumbil). Food Hydrocoll 18:395-401

Chaijan M, Benjakul S, Visessanguan W, Faustman C (2004) Characteristics and gel properties of muscles from sardine (Sardinella gibbosa) and mackerel (Rastrelliger kanagurta) caught in Thailand. Food Res Int 37:1021-1030

Connan S, Stengel DB (2007) Environmental control of brown algal phenol production and assessment of their metal binding properties. 1st environmental change institute research day, NUI Galway

De Freitas V, Mateus N (2001) Structural features of procyanidin interactions with salivary proteins. J Agric Food Chem 49:940-945

Hwang P, Wu C, Gau S, Chien S, Hwang D (2010) Antioxidant and immune-stimulating activities of hot water extract from seaweed Sargassum hemmiphyllum. J Mar Sci Technol 18:41-46

Kuda T, Tsunekawa M, Hishi T, Araki Y (2005) Antioxidant properties of dried 'kayamo-nori', a brown alga Scytosiphon lomentaria (Scytosiphonales, Phaeophyceae). Food Chem 89:617-622

Laemmli UK (1970) Cleavage of structural proteins during assembly of head of bacteriophage T4. Nature 227:680-685

Meilgaard M, Civille GV, Carr BT (1990) Sensory Evaluation Techniques. CRC Press Inc., Florida

Pansera MR, Iob GA, Atti-Santos AC, Rossato M, Atti-Serafini L, Cassel E (2004) Extraction of tannin by Acacia mearnsii with supercritical fluids. Braz Arch Biol Technol 47:1-7

Parr AJ, Bolwell GP (2000) Phenols in the plant and in man. The potential for possible nutritional enhancement of the diet by modifying the phenol content or profile. J Sci Food Agric 80:985-1012

Prigent SVE, Gruppen H, Visser AJ, Van Koningsveld GA, de Jong GAH, Voragen AGJ (2003) Effects of non-covalent interactions with 5-O (ortho)-caffeoylquinic acid (chlorogenic acid) on the heat denaturation and solubility of globular proteins. J Agric Food Chem 51:5088-5095

Ragan M, Glombitza K (1986) Phlorotannins, brown algal polyphenols. In: Round FE, Chapman DJ (eds) Progress in Phycological Research, Biopress, Bristol 4:129-241

Rawdkuen S, Benjakul S (2008) Whey protein concentrate: autolysis inhibition and effects on the gel properties of surimi prepared from tropical fish. Food Chem 106:1077-1084

Rawel HM, Czajka D, Rohn S, Kroll J (2002) Interactions of different phenolic acids and flavonoids with soy proteins. Int J Biol Macromol 30:137-150

Robinson HW, Hodgen CG (1940) The biuret reaction in the determination of serum protein. I. A study of condition necessary for the production of the stable colour which bears a quantitative relationship to the protein concentration. J Biol Chem 135:707-725

Strauss G, Gibson SM (2004) Plant phenolics as cross-linkers of gelatin gels and gelatin-based coacervates for use as food ingredients. Food Hydrocoll 18:81-89

Vimalabai C, Prathiba RA, Sumithra P (2004) Phenolic compounds in brown seaweeds from Tuticorin, southeast coast of India. Seaweed Res Util 26(1-2):93-98

Zahra R, Mehrnaz M, Farzaneh V, Kohzad S (2007) Antioxidant activity of extract from a brown alga, Sargassum bovenum. Afr J Biotechnol 6(24):2740-2745

Zubia M, Payri C, Deslandes E (2008) Alginate, mannitol, phenolic compounds and biological activities of two range extending brown algae, Sargassum mangarevense and Turbinaria ornata (Phaeophyta: Fucales), from Tahiti (French Polynesia). J Appl Phycol 20:1033-1043 